\title{
RELATIONSHIP BETWEEN VEGETATION INDICES AND AGRONOMIC PERFORMANCE OF MAIZE VARIETIES UNDER DIFFERENT NITROGEN RATES
}

\author{
RELAÇÃO ENTRE ÍNDICES DE VEGETAÇÃO E DESEMPENHO AGRONÔMICO \\ DE VARIEDADES DE MILHO SOB DIFERENTES DOSES DE NITROGENIO
}

\author{
Marcela da Silva FLORES ${ }^{1}$; Willian Menitti PASCHOALETE'; Fabio Henrique Rojo BAIO'; \\ Cid Naudi Silva CAMPOS ${ }^{1}$; Ariane de Andréa PANTALEÃO ${ }^{1}$; \\ Larissa Pereira Ribeiro TEODORO'; Carlos Antônio da SILVA JÚNIOR²; \\ Paulo Eduardo TEODORO ${ }^{1 *}$ \\ 1. Universidade Federal de Mato Grosso do Sul, Chapadão do Sul, MS, Brasil; 2. Universidade do Estado do Mato Grosso, Sinop, MT, \\ Brasil.*eduteodoro@hotmail.com
}

\begin{abstract}
Precision agriculture is a set of techniques that assist the monitoring of the agronomic performance of the maize crop by using vegetation indices. This study aimed to verify the relationship between vegetation indices, plant height, leaf $\mathrm{N}$ content, and grain yield of three maize varieties, grown under high and low $\mathrm{N}$ as topdressing. The experiment was carried out at the Fundação de Apoio à Pesquisa Agropecuária de Chapadão (Fundação Chapadão), located in the municipality of Chapadão do Sul, during the 2017/2018 season. The experiment consisted of a randomized block design with four replications, arranged in a $3 \times 2$ split-plot scheme. The first factor (plots) corresponded to three open-pollinated maize varieties (BRS 4103, BRS Gorotuba, and SCS 154), and the second factor (subplots) consisted of two N rates applied as topdressing (80 and $\left.160 \mathrm{~kg}^{-1}\right)$. All the evaluated variables showed varieties $\mathrm{x} \mathrm{N}$ interaction. Vegetation indices in maize varieties were influenced by the $\mathrm{N}$ rate applied as topdressing. Normalized Difference Vegetation Index (NDVI) and Soil-adjusted Vegetation Index (SAVI) showed a higher correlation with plant height. At the same time, Normalized Difference Red Edge (NDRE) had a stronger association with leaf N content.
\end{abstract}

KEYWORDS: NDRE. NDVI. SAVI. Remote sensing. Zea mays.

\section{INTRODUCTION}

Maize (Zea mays L.) is the world's largest cereal crop, accounting for 981 million tons of grain in 2019. Brazilian maize production in the 2018/2019 season was estimated in 100 million tons. of which 73.2 million tons were produced in the off-season, with a mean yield of $5,682 \mathrm{~kg} \mathrm{ha}^{-1}$ (CONAB, 2020). The production of off-season maize has increased each year. The area cultivated with maize crops in the country is 17.5 million hectares. The state of Mato Grosso do Sul is the third-largest national producer of off-season maize, accounting for about 9.6 million tons in the 2019/2020, with a planted area of approximately 1.8 million hectares (CONAB, 2020).

Currently, the production of off-season maize is higher than the actual season. Initially, maize crops were grown with little investment and had low yield, causing producers dissatisfaction. However, due to the low cost of the off-season maize production, producers have insisted on this activity. The germplasm source available for use consists of single, double, and triple hybrids and open-pollinated varieties. The use of these materials depends on the technological level of production and the climatic risks of the growing region. In the region of Chapadões, in the Midwest Brazilian Cerrado, maize is mostly grown in the off-season, after soybean or cotton harvest. For being highly rustic, maize varieties are an interesting alternative due to the climatic instability of this region. Moreover, their seeds are cheaper when compared with hybrids. Currently, precision agriculture has been used to monitor the crop throughout the cultivation. Precision agriculture is a set of techniques that allows for the specific management of crops and the optimization of production expenses by knowing the variability of different factors, such as soil fertility, pest and disease incidence, and the physiological condition of the plant (XU; SU, 2017; GAO et al., 2018; SCHWALBERT et al., 2020). One of the main techniques of precision agriculture is remote sensing (RS), a non-destructive and accurate method for monitoring and characterizing areas or objects.

Vegetation indices (VIs), obtained by the relation between different wavelengths captured by 
a sensor, is one of the RS techniques most widely used in the evaluation of vegetation cover, vigor and growth dynamics, nutritional status, among other applications (XU; SU, 2017; BAIO et al., 2018; SILVA JUNIOR et al., 2018). Some VIs that show a high correlation with plant height and leaf nitrogen content (LN) can be obtained from the data collected by active optical sensors. For instance, the Normalized Difference Vegetation Index (NDVI) is highly correlated to plant height when compared with the Red-Edge Vegetation Index (VI Red Edge). On the other hand, the Normalized Difference Red Edge (NDRE) is correlated with the $\mathrm{N}$ content (RAPER; VARCO, 2015). Baio et al. (2018) used different vegetation indices to estimate the application rate and leaf deposition in maize, and their result allows better planning of several agricultural operations. Thus, this study aimed to verify the relationship between vegetation indices, plant height, leaf $\mathrm{N}$ content, and grain yield of three maize varieties, grown under high and low $\mathrm{N}$.

\section{MATERIAL AND METHODS}

The experiment was carried out at Fundação de Apoio à Pesquisa Agropecuária de Chapadão (Fundação Chapadão), located in the municipality of Chapadão do Sul (1841'33"S, 5240'45"W, 810 m high), Mato Grosso do Sul. The climate of the region is characterized as Savana Tropical (Aw). The soil is classified as Clayey Dystrophic Red Latosol. The experiment consisted of a randomized block design with four replications, arranged in a $3 \times 2$ split-plot scheme. The first factor (plots) corresponded to three open-pollinated maize varieties (BRS 4103, BRS Gorotuba, and SCS 154), and the second factor (subplots) consisted of two $\mathrm{N}$ rates applied as topdressing (80 and $160 \mathrm{~kg}^{-1}$ ).

The experiment was installed in November 2017, using a $0.45 \mathrm{~m}$ spacing between rows and 2.5 plants $\mathrm{m}^{-1}$, totaling a stand of 55,555 plants $\mathrm{ha}^{-1}$. Each experimental unit (subplot) was composed of five 5.5-m rows. A rate of $300 \mathrm{~kg} \mathrm{ha}^{-1}$ of NPK (0420-20) was used at the experiment installation. When plants were at the V4 stage, $80 \mathrm{~kg} \mathrm{ha}^{-1}$ of $\mathrm{N}$ was applied as topdressing to the total area, using urea as $\mathrm{N}$ source. For the other treatments with a high $\mathrm{N}$ rate $\left(160 \mathrm{~kg} \mathrm{ha}^{-1}\right)$, another topdressing was applied, using $80 \mathrm{~kg} \mathrm{ha}^{-1}$ of $\mathrm{N}$ at the V6 stage.

When the plants were at full bloom, the leaf $\mathrm{N}$ content, plant height, and vegetation index were measured. For analysis of the leaf $\mathrm{N}$ content, the middle third of five leaves were collected according to the recommendation and procedures described in Malavolta et al. (1989). The vegetation indices
Normalized Difference Vegetation Index (NDVI), Normalized Difference Red Edge (NDRE), and Soil-adjusted Vegetation Index (SAVI) were measured using the fixed-wing Unmanned Aerial Vehicle (UAV) Senseflye Bee RKT, with take-off, flight plan, and landing autonomous control. eBee was equipped with the Sensefly Sequoia multispectral sensors. This sensor collects reflectance at green $(550 \mathrm{~nm})$, red $(660 \mathrm{~nm})$, nearinfrared $(735 \mathrm{~nm})$, and infrared $(790 \mathrm{~nm})$ wavelength, with a brightness sensor allowing calibration of the values collected.

The aerial survey was carried out using the RTK (Real Time Kinematics) technology, which estimates the position of the camera at the time of image collection, with $0.025 \mathrm{~m}$ accuracy. The area was overflown at $100 \mathrm{~m}$ of local altitude, providing a spatial resolution of $0.120 \mathrm{~m}$. The images were mosaiced and orthorectified by the Pix4Dmapper software. Grain yield was obtained by harvesting the central rows of each plot and extrapolating the value to $\mathrm{kg} \mathrm{ha}^{-1}$, after correcting the grain moisture to $13 \%$.

Data were subject to analysis of variance (test $\mathrm{F}$ ) to verify the presence of varieties $\mathrm{x} \mathrm{N}$ rates interaction, and means were compared by the Tukey's test at the $5 \%$ of probability. Subsequently, the multivariate analysis of the canonical variables was performed to verify the interrelation between the treatments used and the variables evaluated. These analyses were carried out in the Rbio software (BHERING, 2017). The VI maps and prescription maps were processed by the Geographic Information Systems (GIS) ESRI ArcGis 10.5.

\section{RESULTS AND DISCUSSION}

Table 1 shows the $\mathrm{F}$ values calculated for the variables leaf nitrogen content (LN), plant height $(\mathrm{PH})$, vegetation indices NDVI, NDRE, and SAVI, and grain yield $(\mathrm{Y})$. The effect of varieties $(\mathrm{V})$, Topdressing Nitrogen $(\mathrm{N})$, and $\mathrm{VxN}$ interaction was significant $(p<0.05)$ for all variables evaluated. The estimates of the coefficient of variation $(\mathrm{CV})$ were lower than $10 \%$ for all variables evaluated and denote high experimental precision according to the criteria established by Pimentel-Gomes (2009). The high experimental precision obtained by vegetation indices, whose $\mathrm{CV}$ estimates were below $2 \%$, is fundamental. The present results are inferior to those reported by Baio et al. (2018). The authors evaluated the vegetation indices NDVI and NDRE in maize and obtained estimates between 8 and $12 \%$. 
Table 1. F values calculated for leaf nitrogen content (LN), plant height (PH), NDVI, NDRE, and SAVI vegetation indices, and grain yield (GY) evaluated in three varieties of open-pollinated maize grown under high $\left(160 \mathrm{~kg} \mathrm{ha}^{-1}\right)$ and low $\left(80 \mathrm{~kg} \mathrm{ha}^{-1}\right)$ nitrogen as topdressing.

\begin{tabular}{lcccccc}
\hline Source of Variation & LN & PH & NDVI & NDRE & SAVI & GY \\
\hline Varieties (V) & $7.05^{*}$ & $15.05^{*}$ & $67.15^{*}$ & $87.30^{*}$ & $233.49^{*}$ & $7.09^{*}$ \\
Topdressing Nitrogen (N) & $14.5^{*}$ & $6.07^{*}$ & $5.82^{*}$ & $138.79^{*}$ & $6.25^{*}$ & $44.54^{*}$ \\
VxN & $6.44^{*}$ & $7.01^{*}$ & $8.79^{*}$ & $23.95^{*}$ & $13.59^{*}$ & 10.46 \\
\hline Coefficient of variation of the plot (\%) & 5.46 & 7.50 & 0.39 & 1.00 & 0.93 & 9.26 \\
Coefficient of variation of the subplot (\%) & 3.42 & 9.90 & 0.40 & 1.05 & 1.35 & 8.62 \\
\hline
\end{tabular}

*: significant at the $5 \%$ of probability by the $\mathrm{F}$ test.

Table 2 shows the unfolding of the significant interaction between open-pollinated maize varieties and $\mathrm{N}$ rates applied as topdressing for the variables evaluated. The increase in the $\mathrm{N}$ rate as topdressing increased the concentration of leaf $\mathrm{N}$ and grain yield for the varieties assessed, except for SCS154 regarding leaf N. Likewise, Majerowicz et al. (2002), Machado et al. (2003), and Borges et al. (2006) also verified response of maize varieties to high $\mathrm{N}$ rate as topdressing.

Table 2. Unfolding of the significant interaction between nitrogen rates as topdressing and open-pollinated maize varieties for leaf $\mathrm{N}$ content (LN), plant height (PH), NDVI, NDRE, and SAVI vegetation indices, and grain yield (GY).

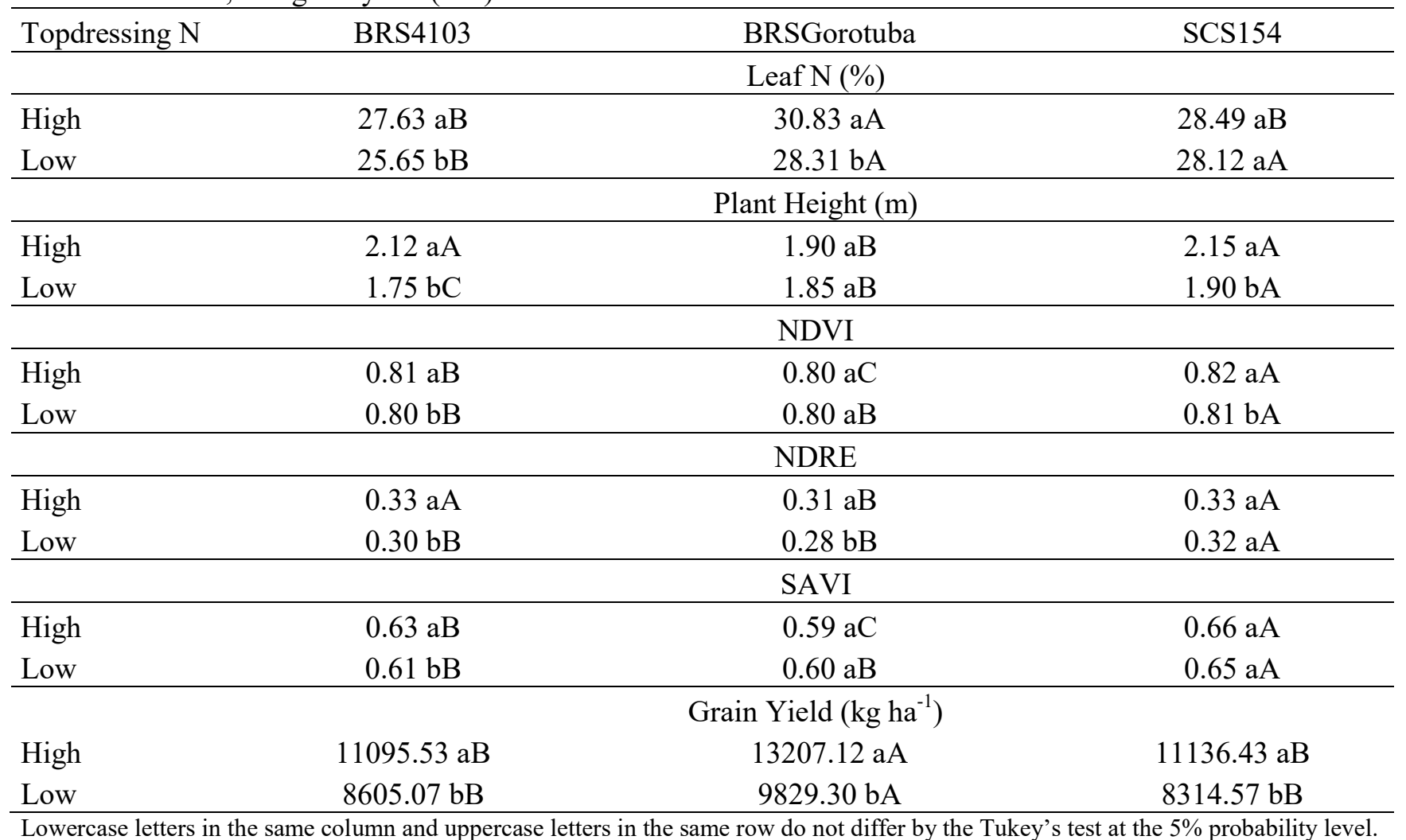

The PH value of varieties BRS 4103 and SCS 154 was higher at a higher nitrogen rate (Table 2). Similarly, varieties had a higher NDVI index at a higher $\mathrm{N}$ rate. However, BRS Gorotuba showed no difference in leaf $\mathrm{N}$ content and NDVI in relation to $\mathrm{N}$ rates applied as topdressing. These results suggest a positive linear association between plant height and NDVI and agree with the results of Baio et al. (2018), who verified a high linear correlation between NDVI and plant height in maize plants.
Regarding NDRE, the $\mathrm{N}$ rates led to differences for varieties BRS 4103 and BRS Gorotuba, revealing a strong association with the results obtained for the leaf $\mathrm{N}$ content. Differences between varieties were observed for all vegetation indices evaluated in this study. These results reinforce the possibility of using precision agriculture in maize breeding programs since the evaluated vegetation indices could separate the spectral behavior of each evaluated variety. 
Precision agriculture has become a necessary practice to increase yield and product quality. Besides providing more profitable conditions, PA allows the monitoring of the crop area, generating data through field analysis and equipment, such as impact penetrometer (SUDDUTH et al., 1994), penetroLOG, and UAVs, to improve the efficiency and durability of production systems.

The canonical variables analysis was used to investigate the simultaneous association between the treatments and the variables evaluated. This multivariate statistical analysis allows reducing the dimensionality of data obtained in the experiment, seeking for combinations of these varied traits in which the correlation of these variables is ignored (KHATTREE; NAIK, 2000). Therefore, this procedure expresses the variation between the treatments and the variables, considering the residual dispersion of each variable. This technique is similar to the principal components analysis but should be preferred when the study uses an experimental design (replications). Each canonical variable is a linear combination of the variables used. To represent the scores on a two-dimensional graph, the percentage of variance accumulated in the first two canonical variables must be greater than $80.0 \%$ (MINGOTI, 2005). In this work, the variance accumulated in the first two canonical variables was $88.0 \%$, allowing a precise interpretation.

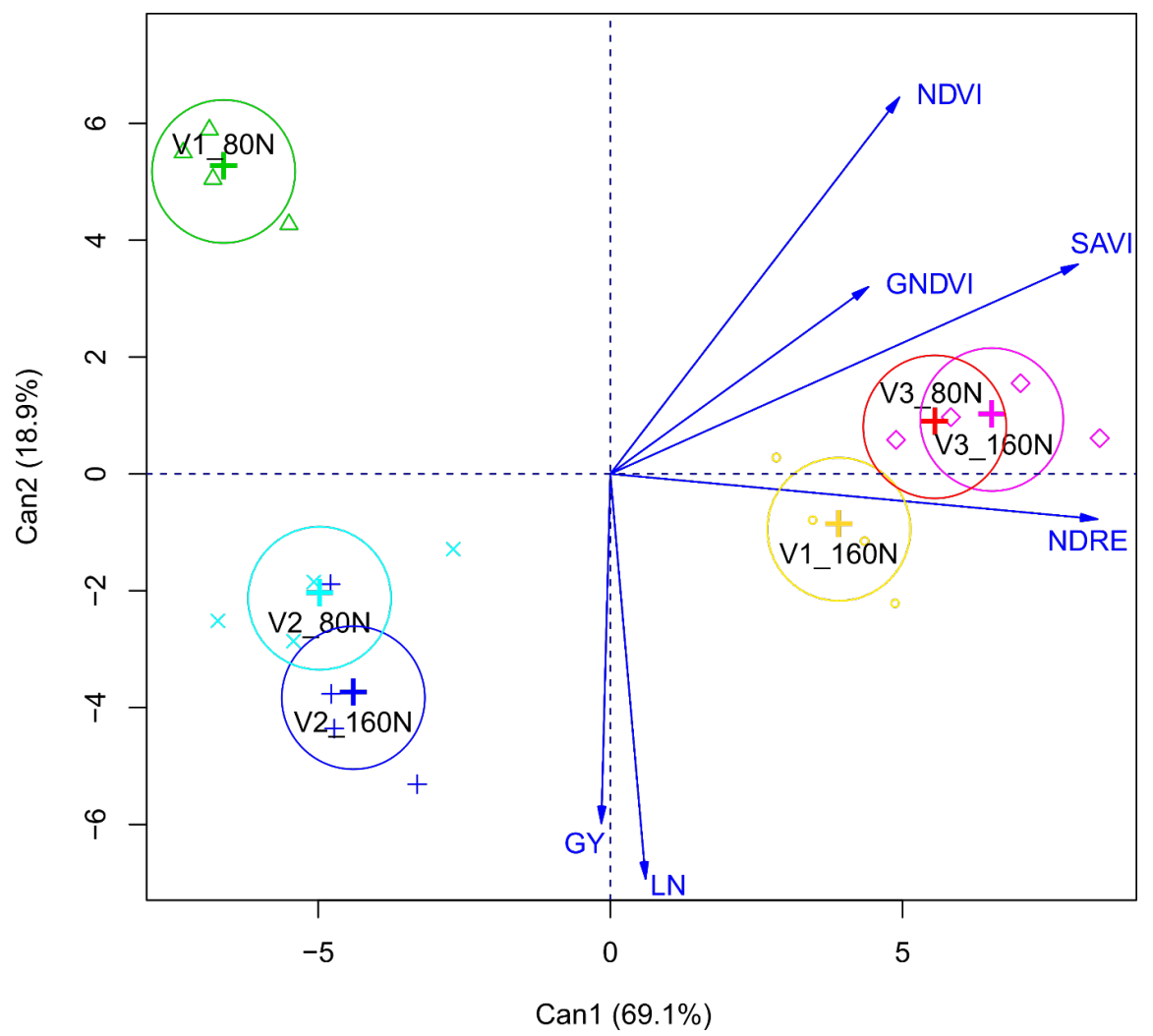

Figure 1. Canonical variables analysis demonstrating the association between the treatments and the variables evaluated. V1: BRS 4103; V2: BRS Gorotuba; V3: SCS 154; LN: leaf nitrogen; PH: plant height; GY: grain yield.

The canonical variables analysis shows that variety BRS Gorotuba was the most yielding and had higher leaf $\mathrm{N}$ content, regardless of the $\mathrm{N}$ rate. Results revealed a high linear association between $\mathrm{PH}$ and the vegetation indices used in this study since the angle between the vectors of these variables was lower than $90^{\circ}$. Conversely, $\mathrm{LN}$ is highly correlated with $\mathrm{Y}$ due to the proximity between their vectors. NDRE was the VI that correlated the most with these variables due to the angle between their vectors, which was lower than $90^{\circ}$.

Nitrogen participates directly in the production of chemical compounds, such as proteins and chlorophylls, which are essential for plant metabolism (ANDRADE et al., 2003). Thus, this nutrient is fundamental at the initial stages of plant growth, when absorption precision is intense (BASSO; CERETTA 2000). Maize is one of the most demanding crops when it comes to fertilizers, especially nitrogen-based. This cereal responds 
expressively to this nutrient, influencing the final production. According to Melgar et al. (1991), $\mathrm{N}$ is the nutrient that has the most significant effect on final maize production.

Similarly, Raper and Varco (2015) observed that NDVI is more associated with plant height, while NDRE is associated with leaf $\mathrm{N}$ content. According to these authors, NDRE correlated more strongly to leaf $\mathrm{N}$ status and total plant $\mathrm{N}$ content when compared with indices that rely on reflectance in green or red regions, such as NDVI. Among the indices evaluated here, NDRE shows the highest relation with grain yield. The spatial variability of this index is shown in Figure 2, where the $\mathrm{N}$ application resulted in higher values of NDRE, regardless of the evaluated variety.
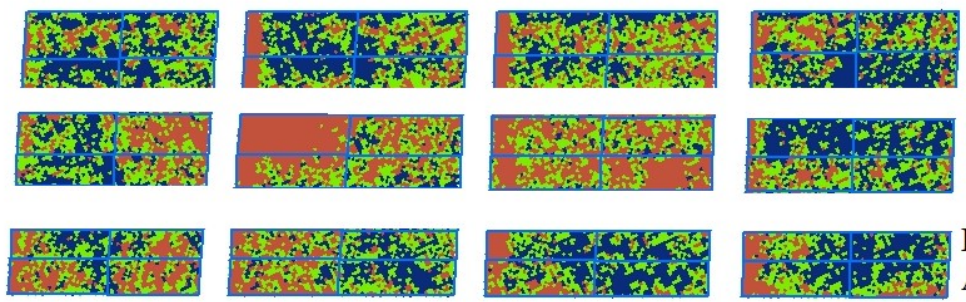

Baixo N Alto $\mathrm{N}$
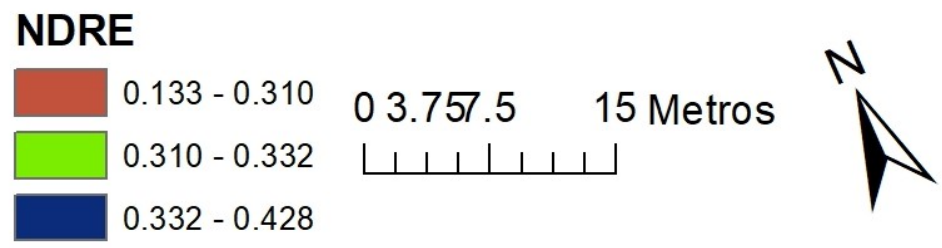

Figure 2. Spatial variability of NDRE evaluated in three maize varieties grown under high and low N rates applied as topdressing.

High NDVI and NDRE values are related to healthy and dense vegetation, which has low reflectance values in the red wavelength (red and red-edge) and high reflectance values in the NIR wavelength (XUE; SU, 2017). The red edge is considered one of the most sensitive regions to changes in chlorophyll and $\mathrm{N}$ status (FITZGERALD et al., 2010; LI et al., 2014). Therefore, the results obtained here reveal the greater efficiency of NDRE in the assessment of the leaf $\mathrm{N}$ content in maize, allowing the discrimination of maize varieties grown under high and low N level conditions. Such findings can contribute to support agricultural decisions related to managing risks within crop production to increase the maize yield.

\section{CONCLUSION}

The vegetation indices analyzed for the different maize varieties were influenced by the $\mathrm{N}$ rate applied as topdressing. NDVI and SAVI indices showed a higher correlation with plant height, while NDRE had a stronger association with leaf $\mathrm{N}$ content.

RESUMO: A agricultura de precisão é um conjunto de técnicas que auxiliam no monitoramento do desempenho agronômico da cultura do milho utilizando índices de vegetação. Este trabalho teve como objetivo verificar a relação entre índices de vegetação, altura de planta, teor de $\mathrm{N}$ foliar e rendimento de grãos de três variedades de milho, cultivadas sob alto e baixo N, em cobertura. O experimento foi realizado na Fundação de Apoio à Pesquisa Agropecuária de Chapadão, localizada no município de Chapadão do Sul, na safra 2017/2018. O experimento consistiu de um delineamento de blocos casualizados com quatro repetições, dispostos em esquema de parcelas subdivididas $3 \times 2$. O primeiro fator (parcelas) correspondeu a três variedades de milho de polinização aberta (BRS 4103, BRS Gorotuba e SCS 154), e o segundo fator (subparcelas) consistiu de duas doses de $\mathrm{N}$ aplicadas como cobertura $\left(80 \mathrm{e} 160 \mathrm{~kg}^{-1}\right)$. Todas as variáveis avaliadas apresentaram interação variedades x N. Os índices de vegetação nas variedades de milho foram influenciados pela dose de $\mathrm{N}$ aplicada como cobertura. Os índices NDVI e SAVI mostraram uma maior correlação com a altura da planta, enquanto o NDRE apresentou uma associação mais forte com o conteúdo de $\mathrm{N}$ foliar.

PALAVRAS-CHAVE: NDRE. NDVI. SAVI. Sensoriamento remoto. Zea mays. 


\section{REFERENCES}

ANDRADE, A. C.; ANDRADE, A. C., FONSECA, D. D., QUEIROZ, D. S.; SALGADO, L. T.; CECON, P. R. Adubação nitrogenada e potássica em capim-elefante (Pennisetum purpureum Schum.cv. Napier). Ciência e Agrotecnologia, v. 27, p. 1643-1651, 2003.

BAIO, F. H. R.; SILVA, E. E.; SOUZA, M. A. V.; ZANIN, A. R. A.; TEODORO, P. E. Vegetation indices to estimate spray application rates of crop protection products in corn. Agronomy Journal, v. 110, p. 1-15, 2018. https://doi.org/10.2134/agronj2017.12.0718

BASSO, C. J.; CERETTA, C. A. Manejo do nitrogênio no milho em sucessão a plantas de cobertura de solo, sob plantio direto. Revista Brasileira de Ciência do Solo, v. 24, n. 4, p. 905-915, 2000.

https://doi.org/10.1590/S0100-06832000000400022

BHERING, L. L. Rbio: A tool for biometric and statistical analysis using the R platform. Crop Breeding and Applied Biotechnology, v. 17, p. 187-190, 2017. https://doi.org/10.1590/1984-70332017v17n2s29

BORGES, E.A.; FERNADES, M.S.; LOSS, A.; SILVA, E.V.; SOUZA, S.R. Acúmulo e remobilização de nitrogênio em variedades de milho. Caatinga, v. 19, n. 3, p. 278-286, 2006.

CONAB. Acompanhamento da safra brasileira de grãos: safra 2019/20, sexto levantamento. Companhia Nacional de Abastecimento (CONAB), Brasília. Disponível em: <https://www.conab.gov.br/infoagro/safras/graos/boletim-da-safra-de-graos>. Acesso em 05 de abril de 2020.

FITZGERALD, G.; RODRIGUEZ, D.; O'LEARY, G. Measuring and predicting canopy nitrogen nutrition in wheat using a spectral index - the canopy chlorophyll content index (CCCI). Field Crops Research, v. 116, p. 318-324, 2010. https://doi.org/10.1016/j.fcr.2010.01.010

GAO, F.; ANDERSON, M.; DAUGHTRY, C.; JOHNSON, D. Assessing the Variability of Corn and Soybean Yields in Central Iowa Using High Spatiotemporal Resolution Multi-Satellite Imagery. Remote Sensing, v. 10, p. 1489, 2018. https://doi.org/10.3390/rs10091489

LI, F., MIAO, Y., FENG, G., YUAN, F., YUE, S., GAO, X.; LIU, Y.; LIU, B.; USTIN, S.L.; CHEN, X. Improving estimation of summer maize nitrogen status with red edge-based spectral vegetation indices. Field Crops Research, v. 157, p. 111-123, 2014. https://doi.org/10.1016/j.fcr.2013.12.018

KHATTREE, R.; NAIK, D.N. Multivariate data reduction and discrimination with SAS software. Cary, NC, USA: SAS Institute Inc., 2000. 558p.

MACHADO, A. T.; MACHADO, C. T. T.; MIRANDA, G. V.; COELHO, C. H. M.; GUIMARÃES, L. J. M. Resposta de variedades de milho a níveis e fontes de nitrogênio. Boletim de Pesquisa e Desenvolvimento. Planaltina: Embrapa Cerrados, 2003. 27p.

MAJEROWICZ, N.; PEREIRA, J. M. S.; MEDICI, L. O.; BISON, O.; PEREIRA, M. B.; SANTOS JUNIOR, U. M. Estudo da eficiência de uso do nitrogênio em variedades locais e melhoradas de milho. Revista Brasileira Botânica, v. 25, p. 129-136, 2002. https://doi.org/10.1590/S0100-84042002000200002

MALAVOLTA, E.; VITTI, G.C.; OLIVEIRA, A. S. Avaliação do estado nutricional das plantas: princípios e aplicações. Piracicaba: Associação Brasileira para Pesquisa da Potassa e do Fosfato, 1989. 201p.

MELGAR, R. J.; SIMITH, T. J.; CRAVO, M. S.; SÁNCHEZ, P. A. Rates and dates of nitrogen fertilizer application for maize on a latossol in the central Amazonia region. Revista Brasileira de Ciência do Solo, v. 15, n. 3, p. 289-296, 1991. 
MOLIN, J. P.; JUNIOR, P. A. V.; NETO, D. D.; FAULIN, G. D. C.; MASCARIN, L. Variação espacial na produtividade de milho safrinha devido aos macronutrientes e à população de plantas. Revista Brasileira de Milho e Sorgo, v. 6, n. 3, 2010. https://doi.org/10.18512/1980-6477/rbms.v6n3p309-324

PIMENTEL GOMES, F. Curso de estatística experimental. 15.ed. Piracicaba: FEALQ, 2009. 451p.

RAPER, T. B.; VARCO, J. J. Canopy-scale wavelength and vegetative index sensitivities to cotton growth parameters and nitrogen status. Precision Agriculture, v. 56, p. 345-353, 2015.

SCHWALBERT, R. A.; AMADO, T.; CORASSA, G.; POTT, L. P.; PRASAD, P. V.; CIAMPITTI, I. A. Satellite-based soybean yield forecast: Integrating machine learning and weather data for improving crop yield prediction in southern Brazil. Agriculture and Forest Meteorology, v. 284, 107886, 2020.

https://doi.org/10.1016/j.agrformet.2019.107886

SILVA JUNIOR, C. A.; NANNI, M. R.; SHAKIR, M.; TEODORO, P. E.; DE OLIVEIRA-JÚNIOR, J. F.; CEZAR, E.; SHIRATSUCHI, L. S. Soybean varieties discrimination using non-imaging hyperspectral sensor. Infrared Physics and Technology, v. 89, p. 338-350, 2018. https://doi.org/10.1016/j.infrared.2018.01.027

SUDDUTH, K. A.: BORGELT, S. C: BIRRELL, S. J.; KITCHEN, N. R. Withinfield location anel sensing technology. Columbia: University of Missouri. 1994. 12p.

XUE, J.; SU, B. Significant remote sensing vegetation indices: A review of developments and applications. Journal of Sensors, v. 2017, p. 1-17, 2017. https://doi.org/10.1155/2017/1353691 